\title{
Surveillance \& Society \\ Unsettling Aerial Surveillance: Surveillance Studies after Standing Rock
} Dialogue

\section{J.D. Schnepf}

Princeton University, USA

jschnepf@princeton.edu

\begin{abstract}
Aerial surveillance by unmanned aerial vehicles (UAVs) or drones played a prominent role in the "water is life" actions undertaken by "water protectors" to defend the Standing Rock Sioux Reservation's water source from the proposed Dakota Access Pipeline (DAPL). By considering how the water protectors deployed drones in their actions, this article shows that decolonizing surveillance studies in the settler-colonial context must follow the work of Indigenous studies scholars in accounting for existing colonial relations. To that end, this article argues that while aerial sousveillance measures constitute a subversive tactical response to organized surveillance by law enforcement and private security firms, the technologies and visualizations on which protest drones depend are imbricated in the workings of capital and empire.
\end{abstract}

\section{Introduction}

Arriving at the Oceti Sakowin Camp outside the Standing Rock Sioux Reservation in late November 2016, indigenous studies scholar and citizen of the Lower Brule Sioux Tribe Nick Estes (2019: 3) observed the camp was "completely encircled by law enforcement employing hundreds of miles of concertina wire, road blocks, and twenty-four-hour aerial surveillance, in what resembled a military occupation." Aerial surveillance by unmanned aerial vehicles (UAVs), or "drones," as they are more commonly known, assumed a highly visible role in the \#NoDAPL and "water is life" actions that took place on unceded lands in Standing Rock, North Dakota, from April 2016 to February 2017. For ten months, "water protectors" sought to defend the region's water against the proposed \$3.8 billion Dakota Access Pipeline (DAPL) - an oil pipeline financed by Energy Transfer Partners that would cut through indigenous territory before crossing under Mni Sose (the Missouri River) just north of Lake Oahe and the reservation. The pipeline's proposed proximity to the river threatened to contaminate the only source of drinking water for the people of Standing Rock as well as those living further downstream.

Given that pervasive surveillance has become a common feature of the US security state after 9/11, perhaps the around-the-clock aerial surveillance that Estes encountered at the camp is not surprising. Put in the context of the settler-colonial nation-state's legacy of violence visited on indigenous peoples and lands, though, the adoption of aerial surveillance technologies over reservation lands invites careful scrutiny. In the hands of law enforcement agents and private security firms working on behalf of state and corporate interests, these technologies encroach on sovereign air space in order to control natural resources on the ground. In this way, drone surveillance technologies perpetuate a familiar settler-colonial agenda.

Indigenous scholars have established the foundations for an anti-colonial analysis of aerial surveillance practices in this context. As Glen Coulthard (2013) has written: "Our efforts to decolonize must directly 
confront more than just economic relations; they must account for the complex ways that capitalism, patriarchy, white supremacy, and the state interact with one another to form the constellation of power relations that sustain colonial patterns of behavior, structures, and relationships." The constellation of power Coulthard identifies underwrites all aspects of ongoing settler-colonial relations and the surveillance practices that attend them. This includes the tactics adopted by those seeking to end ongoing colonial violence as well. With the adoption of drone technologies among domestic law enforcement agencies, activists have responded in turn by deploying networked consumer drones to conduct countersurveillance. Practitioners and media scholars alike have touted consumer drones as powerful tools for effective political protest (McCosker 2015; Tuck 2018). This development requires that scholars of surveillance carefully appraise the tactical use of aerial surveillance to achieve anti-colonial ends.

In what follows, I examine how the countersurveillance measures taken by water protectors at Standing Rock constitute a subversive response to corporate and statist organizational surveillance, one that highlights indigenous lands and narratives. At the same time, however, the deployment of aerial imaging equipment requires protectors to rely on historically militarized technologies and modes of seeing. Moreover, the use of this technology links the anti-colonial aim of water protection to the consumer drone's material imbrications with global capitalism and the military-industrial complex. These connections must be acknowledged and assessed if we are to unsettle the study of domestic drone surveillance.

\section{Aerial Sousveillance}

Turning to aerial surveillance to track and document the actions of the oil industry and the state, drone activists at Standing Rock attempted to destabilize conventional power dynamics by indigenizing networked surveillance technologies in an effort to unsettle their conventional coupling to settler-colonial ideologies. In the hands of the water protectors, consumer drones gathered aerial images of Standing Rock and its surroundings to reshape colonial narratives issued by settler-state and corporate actors. Activists also flew their drones over law enforcement and extractive industrial practices in an act of "sousveillance" or surveillance from below. Using surveillance techniques to observe authorities "disrupts the power relationship of surveillance" by appropriating tools typically turned to by those groups seeking to enforce social control (Mann, Nolan, and Wellman 2003: 347). In several cases, water protectors turned their camera-mounted drones back on the state, using the networked capacities of this technological assemblage to publicize the actions of law enforcement via social media posts and livestreams.

From their perspective in the sky, drones could readily discern the scale of the police actions; their images captured law enforcement deploying militarized weapons such as tear gas and water cannons to quell water protectors into compliance. In addition to documenting police activities, protectors flew drones beyond the encampments to the surrounding land. There, the aerial surveillance of the pipeline construction provided visual documentation of environmental degradation. In one instance, drones captured the building of a drill pad intended to bore into the earth to lay pipe, an endeavor otherwise hidden from protectors and the public behind concrete walls (Dewey 2017a). By exposing the scope and scale of the extractive industry's infrastructural ambitions in this region, water protector sousveillance successfully revealed to the American public the environmental violence caused by the pipeline's construction.

Beyond the documentation of environmental degradation afforded by sousveillance practices, drone technologies furnished water protectors with the means to render indigenous knowledge systems visible from a new vantage. In still and moving images, drone-mounted cameras captured and communicated the state of land and water from the air. For example, protector Myron Dewey (2017b) shot and shared footage of earth eroded by moving water that conveyed how Mni Sose has moved through the landscape unimpeded and of its own accord. This form of digital documentation and dissemination serves pedagogical aims by linking indigenous knowledge to global networks of communication; as the homepage of Dewey's Digital Smoke Signals website puts it: "Walking the Footsteps of our Ancestors we educate the world through eLearning, social networking \& Film-making" (Dewey 2019). Visualizing indigenous narratives of the land 
through the technological assemblage of the drone, Dewey extends local knowledge by remediating it for digital distribution.

Practices such as those cited above have prompted some scholars to argue not only that the indigenization of aerial surveillance by water protectors constitutes a "resignification of the aerial view as a countercolonial perspective" but also that this use effectively uncouples drone surveillance technologies from settler-colonial state violence (Tuck 2018: 173). I would argue, however, that the move to disarticulate the domestic use of drone surveillance from colonial ideology, even in isolated instances, is not possible through the promise of potential visual resignification. Despite the anti-colonial aims that motivate the adoption of aeromobility by water protectors at Standing Rock, a robust framework for decolonizing surveillance studies must address the challenges of shoring up long-term strategic goals such as indigenous sovereignty, selfdetermination, and reparations through short-term tactics such as consumer drone deployment.

\section{The Imbrications of Capital and Empire}

As feminist scholar Inderpal Grewal (2017: 343) has cautioned: "While much of the debate around drones in the United States concerns their use by the military, the power of privatized capital and corporations in this new century suggest that entities other than the state are developing and profiting from these technologies." The imbrications of racial capitalism and drone technologies are important to assess in the case of the \#NoDAPL protest given its reliance on digitized networks for distribution. To be sure, it is now standard practice for contemporary forms of protest to operate within the material and digital environment of "global media networks via mobile camera phones and social media platforms" (McCosker 2015: 1). This development underscores that the distribution of images captured through drone surveillanceregardless of its ends - depends more often than not on global media networks operating in the service of corporate interests (1). Moreover, the manufacture and distribution of consumer drones is indebted to the infrastructures of global capitalism: for instance, the Phantom Drone, an accessible consumer drone used by many of the \#NoDAPL pilots, is manufactured by Shenzhen Dajiang Baiwang Technology Co., Ltd. in Shenzen, China (DJI 2019) - a global hub for the cheap manufacture of electronics due to the Chinese government's relaxed oversight of human labor laws. Writing about disenfranchised electronic manufacturing industry workers of color in the US, Lisa Nakamura (2014: 919) warns that "some must labor invisibly for others of us to feel, if not actually be, free and empowered through technology use." In the case of Standing Rock, then, reliance on the Phantom Drone to disrupt extractivist capitalism in the short-term does not accord with long-term political goals of racial and economic justice since the mass-marketed consumer drone derives from private capital and the exploitation of invisible labor from a racialized workforce.

Historically, consumer drone technology builds on research developed by the US Department of Defense's notorious Defense Advanced Research Projects Agency (Rhee 2018: 7). The recent domestication of the consumer drone, which occupies the intersection of military research and electronic consumer product, has normalized the practice of training overhead cameras on humans; however, it is important to remember that aerial perspectives are born of militarized technologies and reinforce historically militarized ways of knowing. Early war reconnaissance photography socialized the aerial image's viewer to see like a statethat is, to seek out the tiny human figures potentially hidden within a vast landscape (Sekula 1984: 45). When it comes to contemporary forms of aerial reconnaissance, scholar Jennifer Rhee (2018: 164) claims "surveillance, a technology of racial sorting and subjugation, structures drone technology and its dehumanizing tendencies." While Rhee (2018: 172) writes of the drone's role in acts of state-sanctioned racial violence abroad, keeping in mind the assertion that "racial dehumanization is central to the drone relation" allows us to approach the application of this historically militarized and racialized way of seeing over indigenous peoples and lands with caution. 


\section{Surveillance Ecologies}

When it comes to the deployment of aerial surveillance by law enforcement and private companies, these considerations become especially urgent. Since US military drones regularly trespass into foreign skies with impunity, the drone has become, among other things, an avatar for the state's disregard for the atmospheric sovereignty of communities the world over (Williams 2010). This is true, too, in the case of Standing Rock. Here, the use of domestic drones by Morton County Police and private security company TigerSwan violated the territorial integrity of the Sioux nation and thus impinged on indigenous atmospheric sovereignty. This form of aerial incursion suggests that countering colonial forms of surveillance will require looking to how surveillance materializes, not just in technologies but as ecologies. Anna Feigenbaum and Anja Kanngieser (2015: 81) have termed the settler-state's exercise of control over the skies "atmospheric policing"- a phrase that refers to "those technologies and techniques for controlling populations that are fundamentally predicated on their relationship with air; through requiring air for their transmission and dispersion, they colonize space in ways that other weapons do not." From October through December 2016, the Federal Aviation Administration (FAA) effectively policed the atmosphere over Standing Rock by imposing a series of temporary flight restrictions that limited aerial mobility in a bid to ban private drone operators from disrupting law enforcement helicopters (McNall 2017: 1). Not surprisingly, atmospheric policing severely limited the ability of water protectors to transmit information to the world through digital networks, illustrating how the extension of the settler-state's colonialist practices skyward has perceptible material consequences.

Writing of military drones, critic Lisa Parks (2018: 167) has stated that "the drone's vertical mediations can work to reorganize conditions on the ground." Indeed, by attending to atmospheric policing in our discussions around decolonizing surveillance, the present-day practices of dispossession that carve up the ecosphere for capitalist gain come into view. Control of the lithosphere-with its rich petroleum depositsnow depends on control over the atmosphere, while the fate of the hydrosphere falls by the wayside. The link between lithosphere and atmosphere has yoked the protest drone to crude oil in a chiasmic relation: halting the movement of the water protectors' drones will accelerate the distribution of crude oil through the pipeline, while allowing sousveillance machines to move through the skies freely may well prevent crude oil from flowing.

Surveillance practices and the material history of colonialism are deeply imbricated in our colonial present. To address this, scholars seeking to decolonize surveillance studies in the settler-colonial context must be versed in "indigenous political-economic alternative[s] to the intensification of capitalism" that emphasize what Coulthard (2013) has called "grounded normativity" - those "land-based practices and forms of knowledge that emphasize radical sustainability" and run counter to the tenets of capitalist accumulation. So long as the material circulation of nonrenewable resources extracted from the ground remains tied to drone surveillance and regulation in settler-colonial environments, the critical work of unsettling aerial surveillance and imagining otherwise will be necessary.

\section{Acknowledgments}

With thanks to Professor Myron Dewey, MA, for his art and activism; Dr. Caren Kaplan for her Association of American Geographers 2019 presentation “Airspaces: Protest Drones and Atmospheric Politics"; Dr. Adrienne Keene and Gregory Hitch for their curation of the exhibit "Drone Warriors: The Art of Surveillance and Resistance at Standing Rock" at the Haffenreffer Museum of Anthropology; and Dr. Patricia Stuelke for the opportunity to speak with and learn from the students in her course "Arts Against Empire: Fictions of Revolution and Solidarity in the Americas" at Dartmouth College. 


\section{References}

Coulthard, Glen. 2013. For Our Nations to Live, Capitalism Must Die. Unsettling America: Decolonization in Theory \& Practice (blog). November 5, 2013. https://unsettlingamerica.wordpress.com/2013/11/05/for-our-nations-to-live-capitalism-must-die/ [accessed July 31, 2019].

Dewey, Myron. Drill Pad Site. 2017a. Photograph. Haffenreffer Museum of Anthropology. Providence, RI.

Dewey, Myron. Mni Sose. 2017b. Photograph. Haffenreffer Museum of Anthropology. Providence, RI.

Dewey, Myron. 2019. Digital Smoke Signals. http://www.digitalsmokesignals.com [accessed May 29, 2019 ].

DJI. 2019. About DJI. https://www.dji.com/company [accessed May 29, 2019].

Estes, Nick. 2019. Our History is the Future: Standing Rock Versus the Dakota Access Pipeline, and the Long Tradition of Indigenous Resistance. Brooklyn, NY: Verso.

Feigenbaum, Anna, and Anja Kanngieser. 2015. For a Politics of Atmospheric Governance. Dialogues in Human Geography 5 (1): $80-84$.

Grewal, Inderpal. 2017. Drone Imaginaries: The Technopolitics of Visuality in Postcolony and Empire. In Life in the Age of Drone Warfare, edited by Lisa Parks and Caren Kaplan, 343-365. Durham, NC: Duke University Press.

Mann, Steve, Jason Nolan, and Barry Wellman. 2003. Sousveillance: Inventing and Using Wearable Computing Devices for Data Collection of Surveillance Environments. Surveillance \& Society 1 (3): 331-55.

McCosker, Andrew. 2015. Drone Vision, Zones of Protest, and the New Camera Consciousness. Media Fields Journal 9 (2015): $1-14$.

McNall, Patricia A. June 12, 2017. Letter to Lee Rowland, ACLU. https:/www.faa.gov/about/office org/headquarters offices/agc/practice areas/regulations/interpretations/Data/interps/2017 /Rowland-ACLU\%20-\%20(2017)\%20Legal\%20Interpretation.pdf: 1-3. [accessed July 31, 2019].

Nakamura, Lisa. 2014. Indigenous Circuits: Navajo Women and the Racialization of Early Electronic Manufacture. American Quarterly 66 (4): 919-41.

Parks, Lisa. 2018. Rethinking Media Coverage: Vertical Mediation and the War on Terror. New York: Routledge.

Rhee, Jennifer. 2018. The Robotic Imaginary: The Human and the Price of Dehumanized Labor. Minneapolis: Minnesota University Press.

Sekula, Alan. 1984. Photography Against the Grain: Essays and Photo Works, 1973-1983. Halifax: Press of the Nova Scotia College of Art and Design.

Tuck, Sarah. 2018. Drone Vision and Protest. Photographies 11 (2-3): 169-75.

Williams, Alison J. 2010. A Crisis in Aerial Sovereignty? Considering the Implications of Recent Military Violations of National Airspace. Area 42 (1): 51-59. 